УДК 597.2/.5(262.5)

\title{
ИХТИОЛОГИЧЕСКИЕ ИССЛЕДОВАНИЯ НА НИС «ПРОФЕССОР ВОДЯНИЦКИЙ» У ПОБЕРЕЖЬЯ КРЫМА И В РАЙОНЕ ФИЛЛОФОРНОГО ПОЛЯ ЗЕРНОВА В ОСЕННИЙ ПЕРИОД (2010 Г.) И НЕКОТОРЫЕ НОВЫЕ СВЕДЕНИЯ ОБ ИХТИОФАУНЕ ЧЁРНОГО МОРЯ * Царин С.А.
}

ФГБУН ФИЦ «Институт биологии южных морей имени А.О. Ковалевского РАН», г Севастополь, Российская Федерация, e-mail: tsarin@mail.ru

После длительного периода отсутствия ихтиологических исследований на научноисследовательских судах Института биологии южных морей имени А.О. Ковалевского в Чёрном море (за исключением ихтиопланктонных съемок и прибрежных ловов на фелюге) они были проведены в 68-м рейсе НИС «Профессор Водяницкий» осенью 2010 г. Особый интерес представляют ихтиологические наблюдения в районе ботанического заказника Филлофорного поля Зернова, где аналогичные работы не проводились уже несколько десятков лет. В исследованиях были использованы удебные ловы, визуальные наблюдения и случайные поимки рыб. Впервые в этом Филлофорном поле поймана присоска пятнистая Diplecogaster bimaculata (Bonnaterre, 1788) на столь далеком расстоянии от берега, но при этом на глубине обычной для обитания вида. По современном видовому составу рыб Филлофорное поле Зернова можно охарактеризовать как относительно бедный район северо-западной части Чёрного моря. Трофическая цепь рыб представлена следующим образом: шпрот Sprattus sprattus (Linnaeus, 1758) $\rightarrow$ мерланг Merlangius merlangus (Linnaeus, 1758) $\rightarrow$ катран Squalus acanthias Linnaeus, 1758. В ихтиоцен поля Зернова входят как стайные пелагические виды ставрида Trachurus mediterraneus (Steindachner, 1868), шпрот, так и придонные - мерланг, присоска. По сборам в этом районе уточнены максимальные размеры самцов черноморского мерланга - 18,8 см в эконом зонах бывшего СССР. В районе Батилимана отмечена самая глубоководная поимка морского конька Hippocampus hippocampus (Linnaeus, 1758) в Чёрном море

Ключевые слова: Чёрное море; Филлофорное поле Зернова; удебный лов; ихтиофауна; пелагические виды; придонные виды

\section{Введение}

Последний полноценный ихтиологический рейс состоялся на НИС «Профессор Водяницкий» (30 рейс) в 1990 г. в районе Аравийского моря. Долгое время в крайне редких морских экспедициях судна ихтиологический материал по взрослым рыбам не собирался вообще.

После длительного перерыва, связанного с общим экономическим кризисом на территории стран СНГ в связи с распадом СССР, ФИЦ ИнБЮМ в 2010 г. возобновил комплексные исследования Чёрного моря на НИС «Профессор Водяницкий». Судя по многочисленным экспедициям 2010-2020 гг., можно сказать, что подобные исследования стали регулярными. В связи с тем, что осуществлять траления в районе исследования не представлялось возможным, для проведения ихтиологических исследований использовались данные удебных ловов. Особенно важны эти исследования для района украинского ботанического заказника общегосударственного значения Е - «Филлофорного поля Зернова» в северо-западной части Чёрного моря (СЗЧМ), где ихтиологические съёмки не проводились в течение нескольких десятилетий. На данные удебных ловов влияют многие факторы, которые необходимо

\footnotetext{
* Работа выполнена в рамках государственного задания ФИЦ ИнБЮМ по теме «Структурнофункииональная организаџия, продуктивность и устойчивость морских пелагических экосистем» (№ гос. регистрации ААAА-A18-118020790229-7).
} 
учитывать, поэтому они не всегда могут чётко отображать картину количественного распределения рыб. Клёв сильно зависит от погодных условий, от времени года и суток, от биологического состояния рыб, от приманки (в тех случаях, когда она необходима) и, наконец, просто от навыков самого рыболова. Однако даже эти сведения могут принести определенную пользу, тем более что донные траления в Чёрном море полностью запрещены, а в заповедной зоне Филлофорного поля Зернова запрещены не только любые траления, но даже и проход судов (рис. 1).

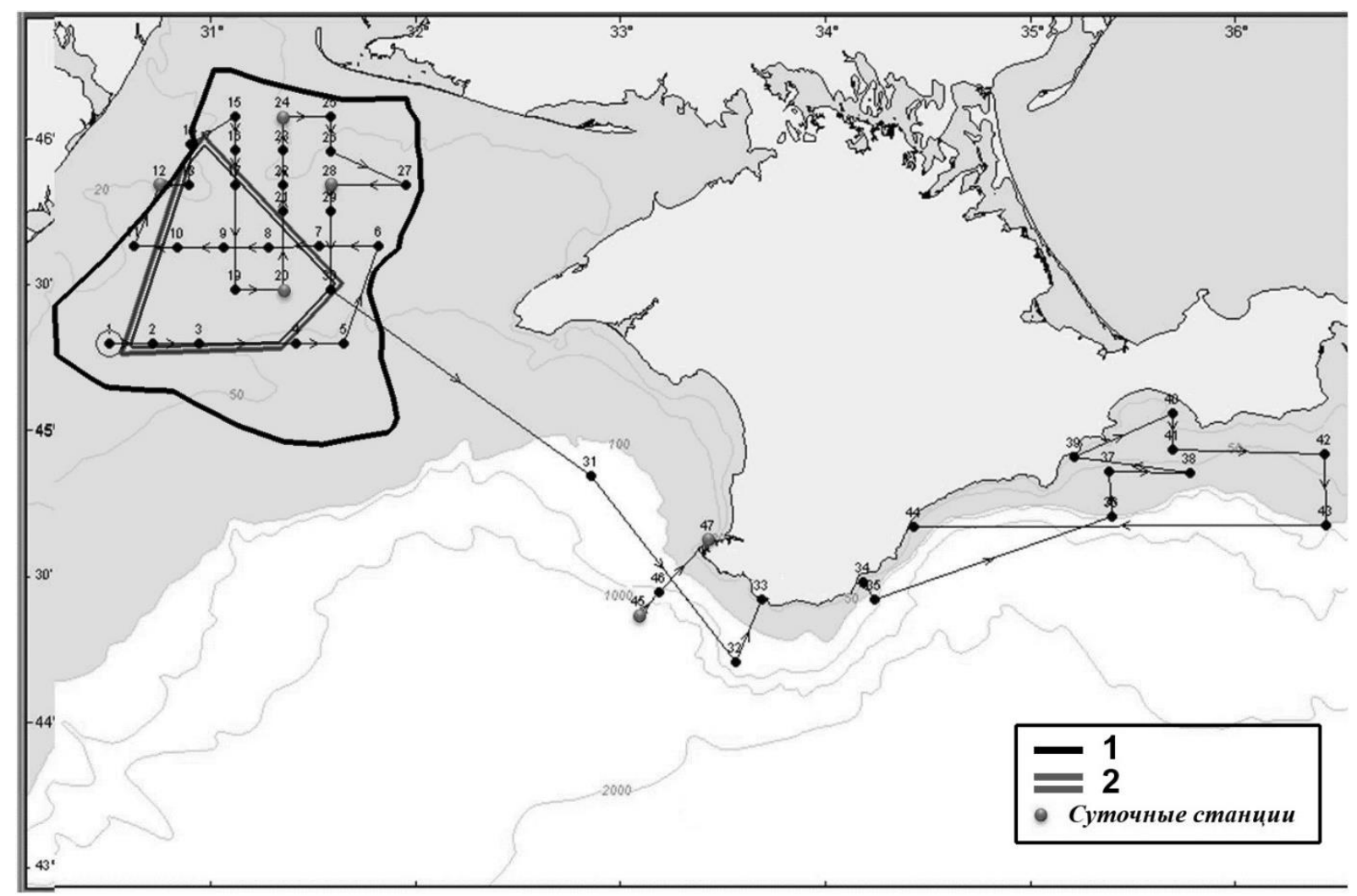

Рис. 1. Маршрут и схема расположения станций 68-го экспедиционного рейса НИС «Профессор Водяницкий» (29.10. - 13.11. 2010 г.): 1 - границы Филлофорного поля по Зернову (1908 г.); 2 - границы ботанического заказника общегосударственного значения «Филлофорное поле Зернова» (указ Президента Украины № 1064/2008 от 21.10.2008 г.).

Целью настоящей работы являлось изучение видового состава рыб и биологического состояния ключевых видов у черноморского побережья Крыма и в районе Филлофорного поля Зернова.

\section{Материалы и методы}

Для исследования взрослой части ихтиофауны в 68 -м рейсе НИС «Профессор Водяницкий» (27.10. - 13.11.2010 г.) (рис. 1) использовались данные удебных ловов, а также визуальные подводные исследования, выполненные водолазом Т.П. Гетьманом, визуальные наблюдения с борта судна и случайные поимки рыб (1 экз. шпрота оказался на судне при выборке якорной цепи, 3 рыбы были в дночерпателе и 1 рыба - в планктонной сети). Рыбы были пойманы на 12 станциях. Биологический анализ включал промеры стандартной и абсолютной длины, определение пола и стадий зрелости, у мерланга брались отолиты для определения возраста, у мерланга и катрана вскрывались желудки. Всего выполнен биологический анализ 464 экз. рыб (402 экз. мерланга Merlangius merlangus (Linnaeus, 1758), 54 экз. ставриды Trachurus 
mediterraneus (Steindachner, 1868), 3 экз. присоски пятнистой Diplecogaster bimaculata (Bonnaterre, 1788), 1 экз. султанки Mullus barbatus ponticus Essipov, 1927, 1 экз. смариды Spicara smaris (Linnaeus, 1758), 1 экз. морского конька Hippocampus hippocampus (Linnaeus, 1758), 1 экз. катрана Squalus acanthias Linnaeus, 1758, 1 экз. шпрота Sprattus sprattus (Linnaeus, 1758). Часть материала была проанализирована непосредственно в рейсе, а часть материала - помещена в Коллекцию гидробионтов Мирового океана ИнБЮМ. Она была проанализирована позже.

\section{Результаты и обсуждение}

По данным разных исследователей в районе Филлофорного поля Зернова отмечалось от 17, 27 (Хуторной, 2004) до 47 видов рыб (Виноградов, 1967) в конце шестидесятых годов прошлого века (табл. 1). Несмотря на то, что многие виды рыб на удочку практически не ловятся, все-таки примерную оценку видового состава рыб по районам исследований можно сделать с учётом визуальных подводных наблюдений и видеосъёмок.

В период наших исследований Филлофорное поле Зернова характеризуется относительно бедным видовым составом рыб. В уловах были отмечены мерланг, ставрида, присоска пятнистая и катран, а по визуальным наблюдениям - шпрот и морские собачки сем. Blenniidae (очевидно длинощупальцевая морская собачка Parablennius tentacularis (Brünnich, 1768)). Совершенно не было в уловах бычков (сем. Gobiidae) - самого многовидового семейства рыб в Чёрном море. Виды этого семейства хорошо ловятся на удочку. По литературным данным в этом регионе отмечено 7 видов бычков, однако в коллекции Зоологического музея Украины (г. Киев) есть только один вид и то из сборов 1969 г. (Манило, 2008-2009).

В этот ихтиоцен входят как стайные пелагические виды - ставрида, шпрот, так и придонные - мерланг, присоска. На Филлофорном поле Зернова были обнаружены только пелагические рыбы, совершающие миграции, часто довольно протяженные, и придонные виды, которые также мигрируют вдоль грунта. Видов, у которых все стадии жизненного цикла протекают (т.е. постоянно обитающих) на Филлофорном поле, нами отмечено не было. Возможно, это связано с периодически возникающими в последние годы заморными явлениями из-за эвтрофикации вод (в основном связанной с дунайскими водами) и сильного взмучивания вод из-за интенсивного судоходства при небольших глубинах даже после прекращения добычи филлофоры в районе Филлофорного поля Зернова (Северо-западная часть..., 2006) и в какой-то степени с особенностями сбора материала. Ряд авторов характеризовали по видовому составу рыб Филлофорное поле Зернова как отдельный район СЗЧМ (Виноградов, 1967, Манило, 2008-2009). Ихтиофауна носила смешанный характер и состояла из видов, в той или иной связанных с водной растительностью, видов песчаных и песчаноракушечниковых грунтов и типично пелагических. Если ранее это Филлофорное поле было своеобразным инкубатором молоди рыб, в том числе и осетровых, и широко использовалось многими видами для нагула и для нереста (Северо-западная часть, 2006), то сейчас поля как такового просто нет, есть отдельные кустики красной водоросли на значительном расстоянии друг от друга, многочисленные скопления пустых створок мидий.

Несмотря на сложность сравнения видового состава рыб по разным причинам (большой временной промежуток между исследованиями, глобальные изменения в биоценозе самого поля, методы получения данных, кратковременность, сезонность и единоразовость нашей съемки и т.д.) по ихтиофауне получилась картина, также удручающая. Нами не отмечено ни одного вида рыб, связанных с песчаным и песчаноракушечниковым грунтом, в том числе и представителей сем. Бычковых, а также султанки Mullus barbatus ponticus, камбалы-калкан Scophthalmus maeoticus, глоссы 
Platichthys flesus, пескарки Gymnammodytes cicerellus, дракончика Trachinus draco и звездочета Uranoscopus scaber, многочисленных по данным предыдущих исследований.

Таблица 1.

Виды рыб, наблюдаемые в районе Филлофорного поля Зернова

\begin{tabular}{|c|c|c|c|}
\hline \multirow{2}{*}{$\begin{array}{l}\text { № } \\
\Pi / \Pi\end{array}$} & Данные по К.А. Виноградов, 1967 & \multicolumn{2}{|c|}{ Наши данные (2010 г.) } \\
\hline & Виды рыб & $\begin{array}{l}\text { Пойманные на удочку (или } \\
\text { другими орудиями лова) }\end{array}$ & $\begin{array}{c}\text { Подводные } \\
\text { наблюдения водолаза }\end{array}$ \\
\hline 1 & Squalus acanthias Linnaeus & + & \\
\hline 2 & Raja clavata Linnaeus & & \\
\hline 3 & Dasyatis pastinaca (Linnaeus) & & \\
\hline 4 & Huso huso (Linnaeus) & & \\
\hline 5 & $\begin{array}{l}\text { Acipenser guldenstaedtii Brandt \& } \\
\text { Ratzeburg }\end{array}$ & & \\
\hline 6 & Sprattus sprattus (Linnaeus) & & + \\
\hline 7 & Alosa immaculata Bennett & & \\
\hline 8 & Engraulis encrasicholus (Linnaeus) & & \\
\hline 9 & Belone euxini Gunther & & \\
\hline 10 & Gaidropsarus mediterraneus (Linnaeus) & & \\
\hline 11 & Merlangius merlangus (Linnaeus) & + & \\
\hline 12 & Syngnathus tenuirostris Rathke & & \\
\hline 13 & S. typhle Pa11as & & \\
\hline 14 & Hippocampus hippocampus (Linnaeus) & & \\
\hline 15 & Mugil cephalus Linnaeus & & \\
\hline 16 & Chelon auratus Risso & & \\
\hline 17 & Ch. saliens Risso & & \\
\hline 18 & Atherina boyeri Risso & & \\
\hline 19 & Trachurus ponticus Aleev & + & \\
\hline 20 & Mullus barbatus ponticus Essipov & & \\
\hline 21 & Ctenolabrus rupestris (Linnaeus) & & \\
\hline 22 & Symphodus cinereus (Bonnaterre) & & \\
\hline 23 & S. ocellatus (Linnaeus) & & \\
\hline 24 & S. roissali (Risso) & & \\
\hline 25 & Trachinus draco Linnaeus & & \\
\hline 26 & Uranoscopus scaber Linnaeus & & \\
\hline 27 & Aidablennius sphynx Valenciennes & & \\
\hline 28 & Coryphoblennius galerita (Linnaeus) & & \\
\hline 29 & Parablennius sanguinolentus Pallas & & \\
\hline 30 & P. tentacularis (Brünnich) & & + \\
\hline 31 & Ophidion rochei Müller & & \\
\hline 32 & Gymnammodytes cicerellus (Rafinesque) & & \\
\hline 33 & Callionymus risso Lesueur & & \\
\hline 34 & Scomber scombrus Linnaeus & & \\
\hline 35 & Sarda sarda (Bloch) & & \\
\hline 36 & Thunnus thunnus (Linnaeus) & & \\
\hline 36 & Aphya minuta (Risso) & & \\
\hline 38 & Gobius niger Linnaeus & & \\
\hline 39 & Mesogobius batrachocephalus (Pallas) & & \\
\hline 40 & Neogobius fluviatilis (Pallas) & & \\
\hline 41 & N. melanostomus (Pallas) & & \\
\hline 42 & Pomatoschistus marmoratus (Nordmann) & & \\
\hline 43 & P. pictus (Ma1m) & & \\
\hline 44 & Scorpaena porcus Linnaeus & & \\
\hline 45 & Scophthalmus maeoticus (Pallas) & & \\
\hline 46 & Platichthys flesus (Linnaeus) & & \\
\hline 47 & Diplecogaster bimaculatus (Bonnaterre) & + & \\
\hline
\end{tabular}


Очевидно, практически нет и рыб, обитающих именно в зарослях водорослей (кроме присоски пятнистой и морских собачек). Не было игловых (сем. Syngnathidae), губановых (сем. Labridae) рыб, морского налима Gaidropsarus mediterraneus, скорпены Scorpaena porcus, саргана Belone euxini, который в этот период наблюдался на поверхности ночью в других регионах в больших количествах. И если некоторые пелагические виды могли отсутствовать просто в силу их редкости в Чёрном море: тунец Thunnus thunnus, скумбрия Scomber scombrus или могли быть не обнаружены ввиду периодичности их миграций: хамса Engraulis encrasicholus, сельдь Alosa immaculata (хотя не факт, что именно по этой причине), то другие виды, вероятно, уже не мигрируют сюда ни для нагула ни для нереста: пеламида Sarda sarda, бланкет Aphya minuta, атерина Atherina boyeri, кефалевые рыбы (сем. Mugilidae). Тоже можно сказать и об осетровых рыбах (сем. Acipenseridae).

В районе Филлофорного поля была поймана присоска пятнистая Diplecogaster bimaculata (Bonnaterre, 1788) с использованием дночерпателя «Океан 50» (2 экз. по 3,1 cм SL) и сети Джеди (1 экз. 1,2 cм SL) (рис. 2). Некоторые исследователи выделяют в составе вида три подвида, два из них D. bimaculata bimaculata (Bonnaterre, 1788) и $D$. bimaculata euxinica Murgoci, 1964 были описаны из Чёрного моря (Eschmeyer, 1999, Muus, Nielsen, 1999), но это вопрос спорный, и в наиболее полную электронную базу данных по рыбам (Fishbase, 2020) эти подвиды не внесены как валидные. Поэтому мы остановимся на виде. Этот вид включен в Красную книгу Украины в 2009 г. (Червона книга..., 2009), 1 экз. из дночерпателя был выпущен в море, а 2 взяты в Коллекцию гидробионтов Мирового океана ИнБЮМ, ранее особей этих рыб в Коллекции не было. Рыбы пойманы на станции № 29 (4545' с.ш. и 31³5' в.д. на глубине 33 м, 07.11.2010 г., $6^{50}-7^{13}$ - дночерпателем и в слое $25-0$ м 06.11.2010 г., $22^{55}-23^{08}-$ сеткой Джеди). Вид не является новым для Филлофорного поля Зернова, но оказалось, что это наиболее удаленные от берегов точки поимки данного прибрежного вида, которые известны в Чёрном море (рис. 3). Присоска была поймана на расстоянии около 53 км до острова Тендровская коса (Херсонская область, Украина) и около 59 км до берега материковой части (по прямой).

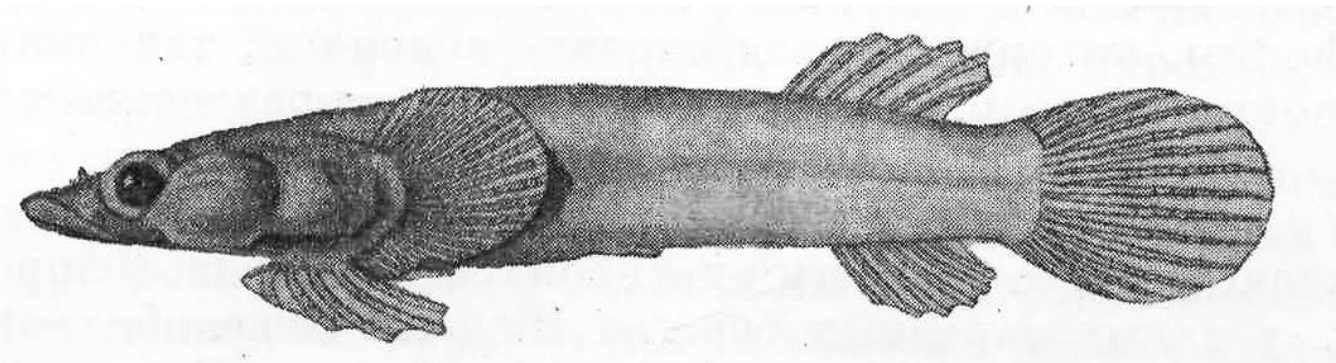

Рис. 2. Присоска пятнистая (по Световидов, 1964)

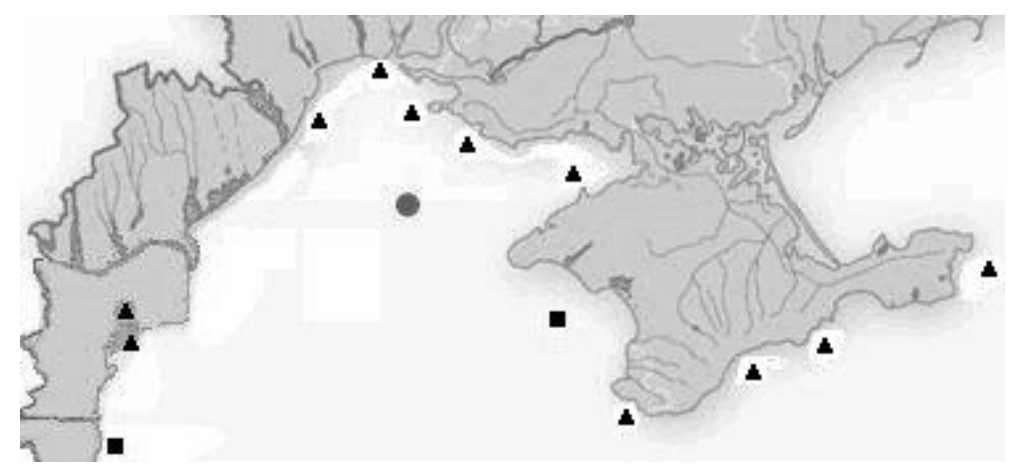

Рис. 3. Точки ловов присоски пятнистой в Черном море по оригинальным и литературным данным ( - данные ИнБЮМ; - данные Fish Base, 2020; $\boldsymbol{\Delta}$ - данные по Красной Книге Украины, 2009) 
Окраска тела этих рыб - красная или красноватая, с бледно-желтыми полосами и пятнами. Значительное количество видов рыб с красноватой окраской и ранее отмечено для Филлофорного поля Зернова: 3 вида зеленушек, султанка, скорпена, бычок бланкет, присоска пятнистая, красноперые сельдь и скумбрия (с красными лучами в плавниках) (Виноградов, 1967; Северо-западная часть..., 2006), а в наших исследованиях присоска пятнистая - это единственный вид рыб с подобной окраской. В длину эти рыбки достигают 5, изредка 7 см. Личинки ведут пелагический образ жизни. Взрослые особи обычно локализуются на глубинах от почти уреза воды до 30 м. Но этот вид держится на гораздо больших глубинах, чем другие присоски: в Средиземном море его ловили на глубинах 80-100 м (Световидов, 1964), а в Атлантическом океане известна даже одна поимка на глубине 490 м.

Взрослые рыбы обитают (используя присоску) на прибрежных скалах, камнях и на плитняке, заросшем цистозирой, на ракушечнике, на песчаных грунтах и в ножках таллома бентосных водорослей. Так что грунт в Филлофорном поле (Строгонов, Гордеева, 2000) вполне подходит для этих рыб. Они и ранее известны из района поля Зернова, куда обычно мигрируют в середине октября (только ближе к берегу). В маеиюне рыбы держатся в прибрежных районах.

Все экземпляры мерланга в рейсе были пойманы в районе Филлофорного поля на глубинах от 37 до 49 м. В целом, по исследуемой акватории, стандартная длина (SL) мерланга находилась в пределах 9,8-24,5 см (средний размер - 14,4 см, модальную группу составили особи длиной 14,1-15,5 см) (рис. 4, рис. 5). У побережья югозападной части Крыма в период с 1998 по 2001 гг. максимальное значение стандартной длинны (SL) было отмечено у самки мерланга и составляло 23,5 см. Согласно литературным сведениям максимальные размеры черноморского мерланга составляют: по данным А.Н. Световидова около 45,2 см (Световидов, 1948), по данным А.Н. Пробатова и И.В. Уральской - 24,4 см (Пробатов, Уральская, 1957), по данным Ю.Г. Алеева - 41,6 см (Алев, 1958), по данным С.В. Володина - 27,5 см (Володин, 1995), а по данным В.Д. Бурдак - 40,7 см (Бурдак 1964) (в необходимых случаях с пересчетом на SL при коэффициенте 1,106). Однако не исключено, что размеры мерланга в Чёрном море могут быть больше (Болтачев, Карпова, 2012). По сведениям В.Д. Бурдак средний размер особей мерланга больше в осенний период, а в северо-западной части моря, куда входит и Филлофорное поле, его размеры крупнее (Бурдак 1964). В то же время в северной части ареала (Атлантика) для мерланга указана длина до 91,5 cм TL (Fishbase, 2002). В нашей работе, в основном, мерланг был представлен особями 2-3-летнего возраста, но встречались экземпляры 4-5 лет размером около 20-25 см, а также одна особь 6-летнего возраста (в настоящее время в Чёрном море особи мерланга возраста свыше четырех лет чрезвычайно редки). Около $35 \%$ особей мерланга были зрелыми (IV-V стадии зрелости), а наиболее крупные особи практически все были на V стадии зрелости. В литературе не было описано случаев поимки в Чёрном море в водах эконом зон бывшего СССР самцов мерланга длиной более 17 cм SL (Световидов, 1948). Однако в прибрежных водах Турции были пойманы и более крупные самцы длиной от 17,6 (Yidiz, Karakulak, 2019), 20,4 (Bilgin et al., 2012), 20,7 (Samsun, 2005), 21,1 (Kalayci et al., 2007) и даже 27,6 cм SL (Genç et al., 1998). Нами в районе исследований был пойман самец длиной 18,8 см SL. В желудках мерланга в основном был шпрот и в незначительной степени двустворчатые моллюски.

В этом районе поймано 9 экз. ставриды. Это были мелкие особи возрастом 1-2 года. Размер ставриды колебался от 8,0 до 13,0 см (в среднем 9,7 см, модальный класс составляли особи 10,6-11,0 cм). Так же был пойман катран длиной 114 cм TL (станция № $2446^{\circ} 04^{\prime}$ с.ш. и $31^{\circ} 21^{\prime}$ в.д., глубина 20 м, 06.11.2010 г., $7^{00}$ ), максимально известная длина вида 208 см TL, обычно до 160 см (Болтачев, Карпова, 2017), хотя и особи длиной более 1 метра в Чёрном море встречаются редко. По нашим данным 
трофическую цепь рыб в этом регионе можно представить следующим образом. Шпрот типичный зоопланктофаг, им питается мерланг, а мерлангом - катран.

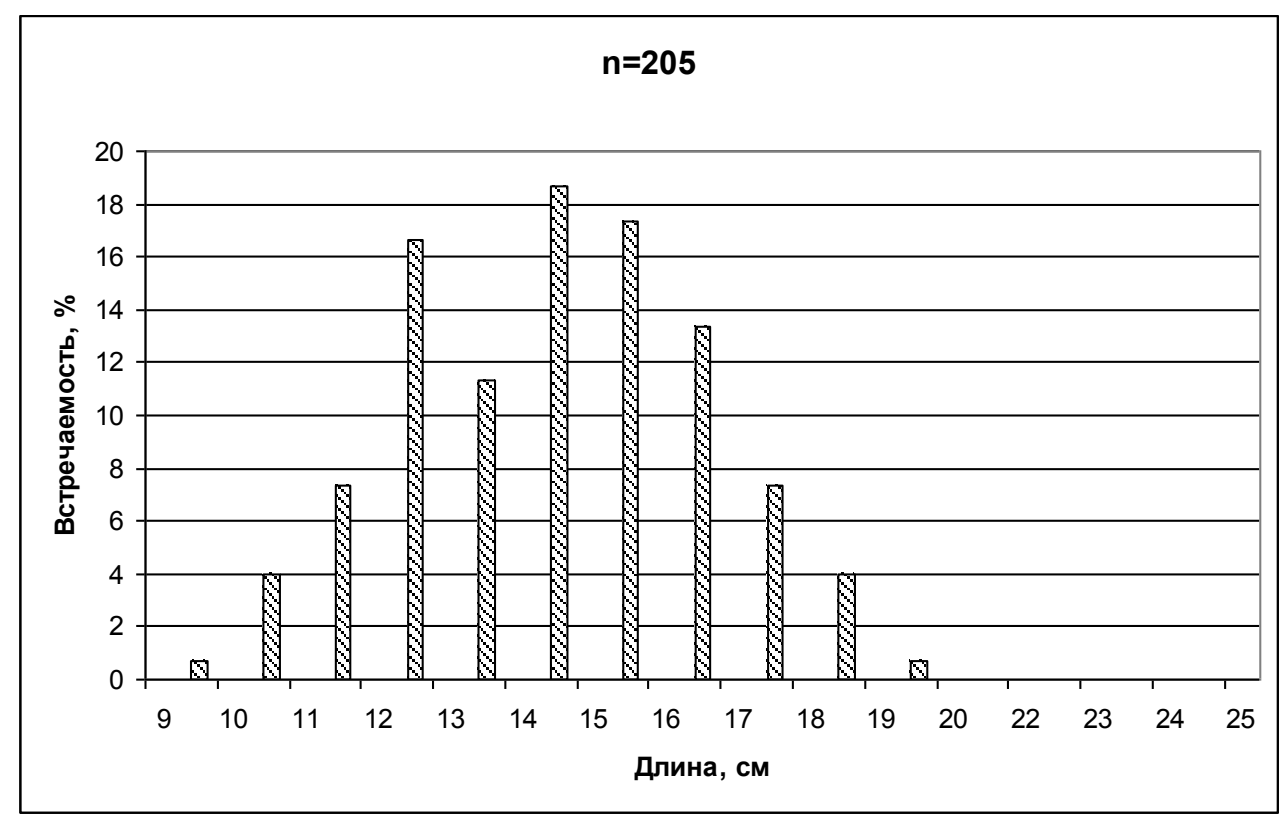

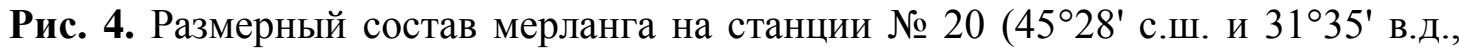
глубина 48-49 м, 04.11.2010 г., $12^{05}-14^{55}$ )

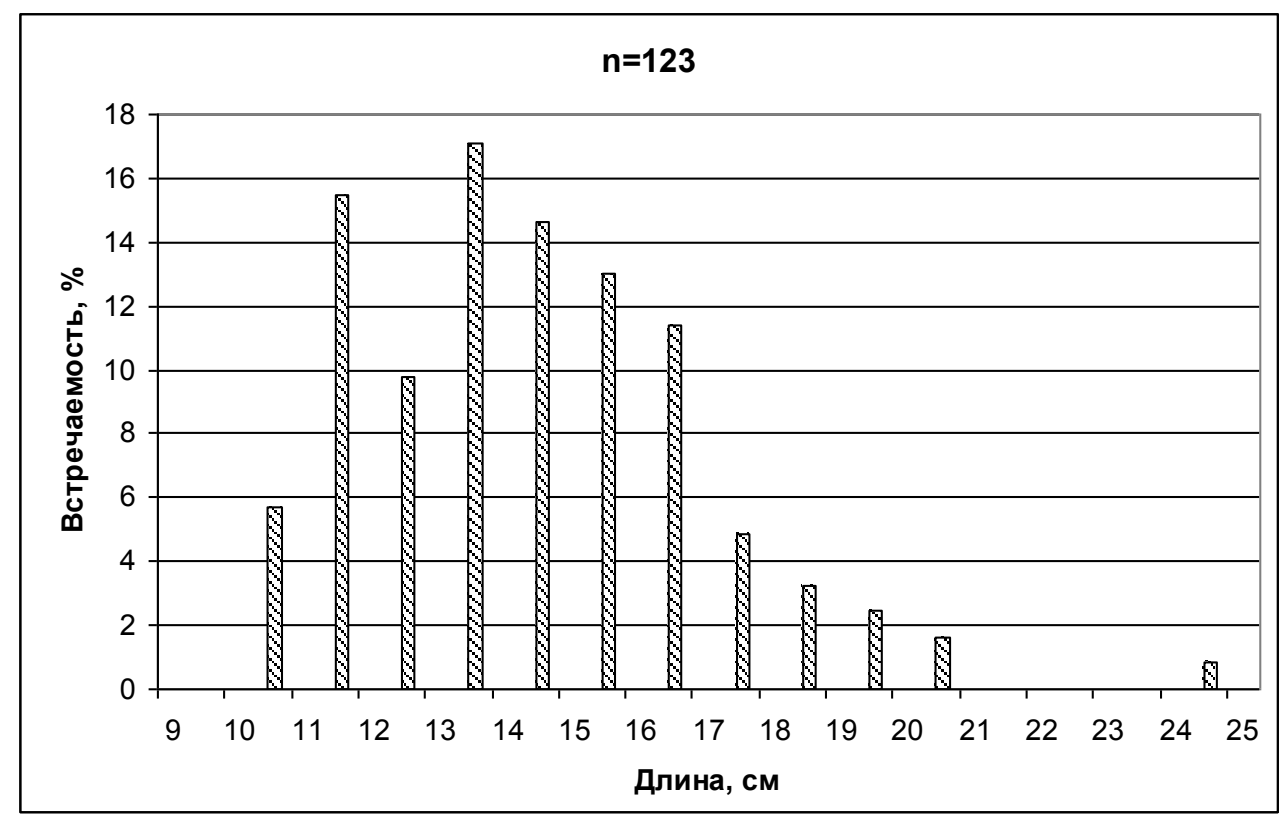

Рис. 5. Размерный состав мерланга на станции № $30\left(45^{\circ} 28^{\prime}-45^{\circ} 29^{\prime}\right.$ с.ш. и $31^{\circ} 35^{\prime}$ в.д., глубина 49 м, 07.11.2010 г., $9^{35}-11^{25}$

В районе у Карадага на двух станциях поймано только 6 экземпляров ставриды

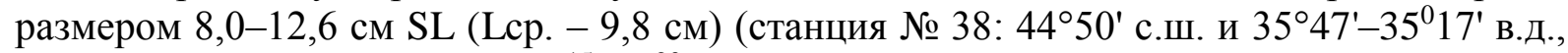
глубина 24 м, 09.11.2010 г., $12^{15}-14^{20}$; станция № 39: $44^{\circ} 54^{\prime}$ с.ш. и $35^{\circ} 12^{\prime}$ в.д., глубина 24 м, 09.11.2010 г., $\left.15^{15}-16^{35}\right)$.

В районе Батилимана был пойман дночерпателем только один морской конек H. hippocampus на станции № 33 (44² $25^{\prime}$ с.ш. и $33^{\circ} 41^{\prime} 7$ в.д., 08.11 .2010 г., $\left.8^{53}-9^{05}\right)$ на глубине 45 м. Согласно литературным данным, обычная глубина обитания этого вида 5-7 м на мелководье, встречается до 12 м, редко до 15-20 м, однако в Чёрном море был 
отмечен и на глубине 30 м (Болтачев, Карпова, 2017, Васильева, 2007, Фауна Украины, 1988). Таким образом, нами зафиксирована наибольшая глубина поимки морского конька из ранее известных в Чёрном море. А вообще в пределах всего ареала вида, включая Средиземное море и Северную Атлантику, известны поимки - на максимальной глубине 60 м (Foster, Vincent, 2004) и даже - 77 м (Garrick-Maidment, 1998). В научной литературе разными авторами приводились разные названия морского конька в Чёрном море. Он был описан и как H. guttulatus Cuvier, 1829 и как $H$. ramulosus Leach, 1814 (последний вид сейчас не считается валидным), по современным данным в Чёрном море обитает только один вид и это - H. hippocampus (Васильева, 2007). Этот вид входит в Красные книги Крыма, Севастополя, Краснодарского края, Украины (Красная книга..., 2015, Красная книга..., 2017, Червона книга, 2009), а также в Международную Красную книгу Чёрного моря (Black Sea..., 1999) и Красную книгу Болгарии (Red Data..., 2015)

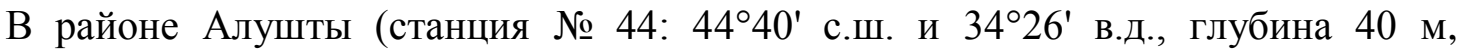
11.11.2010 г., $7^{35}-8^{35}$ ) поймано 39 экз. ставриды длиной 10,0-13,0 см (в среднем 9,8 см, модальный класс составляли особи 9,1-9,5 см), 1 экз. султанки 11,6 см SL и 1 экз. смариды 9,0 см.

При ночных работах с сетями в глубоководном районе на траверзе Севастопольской бухты (станция № 45: 44² $21^{\prime}$ с.ш. и $33^{\circ} 05^{\prime}$ в.д., 11.11.2010 г.) с $22^{15}$ до полуночи на поверхности воды наблюдались многочисленные особи саргана Belone euxini Günther, 1866, по визуальным данным длиной примерно 20-25 см.

Экземпляр шпрота длиной 4,6 см был пойман в Феодосийской бухте.

\section{Выводы}

По сравнению с предыдущими литературными данными (Виноградов, 1967) в районе Филлофорного поля Зернова отмечен относительно бедный видовой состав рыб. Если за предыдущие годы исследований в регионе встречено 47 видов рыб, то в наших исследованиях фигурирует всего 6 видов. Полностью отсутствуют представители песчаных и песчано-ракушечниковых грунтов (бычковых рыб, султанки, дракончика и др.), кроме прироски пятнистой и морской собачки нет рыб, связанных с водной растительностью (игловых, Губановых рыб, саргана и др.). Не зарегистрирован и ряд типичных для региона пелагических рыб (хамса, пеламида, кефалевые и др.).

Отмечена самая удалённая от берега точка поимки присоски пятнистой Diplecogaster bimaculata в Чёрном море. Минимальное расстояние до о. Тендровская коса было около 53 км, а до берега материковой части - 59 км.

Зафиксирована самая глубоководная поимка морского конька Hippocampus hippocampus в Чёрном море (45 м).

\section{Благодарности}

Автор выражает глубокую благодарность водолазу Тарасу Гетьману за детальное описание подводных наблюдений и членам экипажа НИС «Профессор Водяницкий» за помощь в поимке рыб.

\section{Список литературы}

1. Алеев Ю.Г. Об изменении относительной величины плавников у рыб в онтогенезе и филогенеге // Доклады АН СССР. - 1958. - Т. 120. - № 1. С. 204-207.

2. Болтачев A.P., Карпова Е.П. Морские рыбы Крымского полуострова. Симферополь: Бизнес-Информ, 2012. - 224 с. 
3. Болтачев А.Р., Карпова Е.П. Морские рыбы Крымского полуострова. 2-е изд. Симферополь: Бизнес-Информ, 2017. - 376 с.

4. Бурдак В.Д. Биология черноморского мерланга (Odonthogadus merlangus euxinus (Nordmann)) // Труды Севастопольской биологической станции. - 1964. - Т. 15. C. 196-278.

5. Васильева Е.Д. Рыбы Черного моря. Определитель морских, солоноватоводных, эвригалинных и проходных видов с цветными иллюстрациями, собранными С.В. Богородским. - М.: ВНИРО, 2007, - 238 с.

6. Виноградов К.А. Ихтиофауна Филлофорного поля Зернова / Биология северозападной части Черного моря. - Киев, 1967. - С. 232-234.

7. Володин С.B. Популяционная структура и некоторые особенности биологии черноморского мерланга Merlangus merlangus euxinus Nordmann (Teleostei: Gadidae): автореф. дис. ... канд. биол. наук. - Севастополь, 1995. - 24 с.

8. Емтыль М.Х., Иваненко А.М. Рыбы юго-запада России: Учеб. пособие. - Краснодар: Кубанский гос. ун-т, 2002. - 340 с.

9. Красная книга Краснодарского края. Животные. III издание / Отв. ред. А.С. Замотайлов, Ю.В. Лохман, Б.И. Вольфов. - Краснодар: Адм. Краснодар. края, 2017. - $720 \mathrm{c}$.

10. Красная книга Республики Крым. Животные / Отв. ред. д. б. н., проф. С.П. Иванов и к.б.н. А.В. Фатерыга. - Симферополь: ООО «ИТ «АРИАЛ», 2015. - 440 с.

11. Манило Л. Бычковые рыбы (Gobiidae, Perciformes) северо-западной части Черного моря и прилегающих лиманных экосистем // Збірник праць Зоологічного музею. 2008-2009. - № 40. - С. 19-46.

12. Пробатов А.Н., Уральская И.В. Материалы по биологии черноморского мерланга Odonthogadus merlangus euxinus Nordmann // Ученье записки Ростовского госуниверситета. - Ростов на Дону, 1957. - Т. 57, вып. 1. - С. 99-116.

13. Световидов А.Н. Фауна СССР. Рыбы. Трескообразные. - М.-Л.: АН СССР, 1948. T. IX. - Вып.4. - 222 c.

14. Световидов А.Н. Рыбы Черного моря. - М., Л.: Наука, 1964, - 552 с.

15. Северо-западная часть Черного моря: биология и экология. Проект Наукова книга / Зайцев Ю.П., Александров Б.Г., Миничева Г.Г. (ответственные редакторы). - Киев: Наукова думка, 2006. - 700 с.

16. Строгонов А.A., Гордеева И.К. Изучение биоценоза Phyllophora nervosa на Филлофорном поле Зернова с помощью подводного обитаемого аппарата // Экология моря. - 2000. - Вып. 50. - С. 40-44.

17. Фауна Украины. В 40 m. Т. 8. Рыбы. Вып. 3. Вьюновые, сомовые, икталуровые, пресноводные угри, конгеровые, саргановые, тресковые, колюшковые, игловые, гамбузиевые, зеусовые, сфиреновые, кефалевые, атериновые, ошибневые / Мовчан Ю.В. - Киев: Наукова думка, 1988. - 368 с.

18. Хуторной C.A. История изучения ихтиофауны Северо-Западной части Черного моря в пределах территориальных вод Украины и ее изменение под воздействием антропогенного пресса // Экология моря. - 2004. - Вып. 65. - С. 87-93.

19. Червона книга Украӥни. Тваринний світ/ за ред. I.А. Акімова. - К.: Глобалконсалтинг, 2009. - 600 с.

20. Bilgin S., Ba, H., Taşci B. Length Based Growth Estimates and Reproduction Biology of Whiting, Merlangius merlangus euxinus (Nordman, 1840) in the Southeast Black Sea // Turkish Journal of Fisheries and Aquatic Science. - 2012. - 12. - P. - 871-881.

21. Black Sea Red Data Book. Edited by Henri J. Dumont (Ghent, Belgium), Website Editor: V.O. Mamaev (Istanbul, Turkey), Scientific Coordinator: Y.P. Zaitsev (Odessa, Ukraine), 1999. $-413 \mathrm{p}$. 
22. Eschmeyer W.N., (Ed.) Catalog of fishes. Updated database version of November 1999. Catalog databases as made available to FishBase in November 1999. [Электронный pecypc]. Режим доступа: http://research.calacademy.org/ichthyology/catalog

23. Fishbase, 2020 [Электронный ресурс]. Режим доступа: http://www.fishbase.org/

24. Foster S.J., A.C.J. Vincent. Life history and ecology of seahorses: implications for conservation and management // Journal Fish Biology. - 2004. - 65(1). - P. 1-61.

25. Garrick-Maidment, $N$. A note on the status of indigenous species of seahorse // Journal of the Marine Biological Association of the United Kingdom. - 1998. - Vol. 78. - P. 691692.

26. Genç Y., Zengin M., Başar S., Tabak İ., Ceylan B., Çiftçi Y., Üstündă̆ Y., Akbulu, B., Şahin T. Research project of economic aquatic products. TAGEM/IY/96/17/3/001, Final Report, Central Fisheries Research Institute. - 1998. - 157 pp.

27. Kalayci, F., Samsun, N., Bilgin, S. \& Samsun, O. Length-weight relationship of 10 fish species caught by bottom trawl and midwater trawl from the middle Black Sea, Turkey // Turkish Journal of Fisheries and Aquatic Sciences. - 2007. - 7. - P. 33-36.

28. Muus, B.J. and J.G. Nielsen. Sea fish. Scandinavian Fishing Year Book, Hedehusene, Denmark, 1999. - 340 pp.

29. Red Data Book of the Republic of Bulgaria. Volume 3. Natural habitats. Biserkov, V. et al. (Eds). - Sofia, 2015. - 422 pp.

30. Samsun, $S$. The research on the some reproduction and feeding characteristics of the whiting (Gadus merlangus euxinus Nordmann, 1840). PhD. thesis, Ondokuz May1s University, Institute of Science. - 2005. - 103 pp.

31. Yidiz, T., Karakulak, F.S. Age, Growth and Mortality of Whiting (Merlangius merlangus Linnaeus, 1758) from the Western Black Sea, Turkey // Age, Growth and Mortality of Whiting (Merlangius merlangus Linnaeus, 1758) from the Western Black Sea, Turkey // Turkish Journal of Fisheries and Aquatic Sciences. - 2019. - 9. - P. 793-804.

\section{ICHTHYOLOGICAL RESEARCHES ON R/V «PROFESSOR VODYANITSKIY»OF THE CRIMEAN COAST AND IN THE AREA OF ZERNOV PHILLOPHORIC FIELD IN AUTUMN (2010) AND SOME NEW INFORMATION ABOUT ICHTIOFAUNA OF THE BLACK SEA}

Tsarin. S.A.

A.O. Kovalevsky Institute of Biology of the Southern Seas of RAS, Sevastopol, Russian Federation, e-mail: tsarin@mail.ru

After long period of absence of ichthyological researches on the R/V of the A.O Kovalevsky Institute of Marine Biological Research in the Black Sea (except for ichthyoplanktonic surveys and off-shore catches on felucca) they were conducted in the 68th cruise of $\mathrm{R} / \mathrm{V}$ «Professor Vodyanitskiy» in autumn, 2010. Ichthyological supervisions in the region of botanical reserve Zernov phyllophora field are presented special interest, where previous ichthyological works were a few ten years ago. Fishery, visual supervisions and casual catching of fish were used in researches. First Diplecogaster bimaculata (Bonnaterre, 1788) is caught in Phyllophora field on so distant distance from shore, but here on a depth usual for habitat of species. According to the modern fish species composition, the Zernov Phylophore field can be described as a relatively poor area of the North-Western part of the Black sea. The fish trophic chain is presented as follows: Sprattus sprattus (Linnaeus, 1758 ) $\rightarrow$ Merlangius merlangus (Linnaeus, 1758) $\rightarrow$ Squalus acanthias Linnaeus, 1758. Ichthyocoen of Zernov fild are included both schooling pelagic species: Trachurus mediterraneus, Sprattus sprattus and near-bottom: Squalus acanthias, Diplecogaster bimaculata. The maximal size of males Black Sea Merlangius merlangus in the economic zones of the former USSR $-18,8 \mathrm{~cm}$ was specified according to collections in this area. The deepest capture of Hippocampus hippocampus (Linnaeus, 1758) in the Black Sea was recorded in the Batiliman region. 
Keywords: Black Sea, Zernov phyllophora field, fishery, ichthyofauna, pelagic species, near-bottom species.

Царин

Сергей

Анатольевич
Кандидат биологических наук, старший научный сотрудник, ведущий научный сотрудник, руководитель Научно-образовательного центра коллективного пользования «Коллекция гидробионтов Мирового океана», ФГБУН ФИЦ «Институт биологии южных морей имени A.О. Ковалевского РАН», e-mail: tsarin@mail.ru

Поступила в редакциюю 18.02.2020 г. 